\title{
ASSESSMENT OF SEISMIC FRAGILITY OF HISTORICAL BUILDINGS AT THE URBAN SCALE BY TYPOLOGICAL- MECHANICAL APPROACHES: THE CASE STUDY OF FOGGIA
}

\author{
VALERIA LEGGIERI ${ }^{1}$, SERGIO RUGGIERI ${ }^{1}$, GIUSEPPINA UVA ${ }^{1 *}$ \\ ${ }^{1}$ Department DICATECh, Polytechnic University of Bari, Via Orabona, 4 - 70126, Italy \\ e-mail: g.uva@poliba.it (*corresponding author) \\ \{valeria.leggieri; sergio.ruggieri\}@poliba.it
}

Keywords: Masonry buildings, Urban aggregate, Fragility analysis, regional vulnerability analysis

\begin{abstract}
The study of the seismic vulnerability of historical centres, especially in the Mediterranean zone, is one of the main issues in ongoing scientific research. This is due, on the one hand, to the continuous evolution of the seismic demand and, on the other hand, to the high vulnerability of the masonry existing building stock. The seismic events of the last few years highlighted the necessity to perform a large-scale survey of the huge amount of masonry buildings in historical centres, in order to provide prioritization scales for planning mitigation strategies. With this regard, the scientific literature provides several methodologies that allow a rapid assessment based on predefined survey forms. The data obtained from the surveys are usually used as the input for algorithms aimed at estimating the vulnerability level of the building investigated. The aim of the present work is to propose a general framework for analysing seismic vulnerability of masonry historical centres and deriving fragility curves basing on multiple data sources. In particular, using data collected through existing territorial databases, supplemented by a set of vulnerability forms available for the city centre of the Municipality of Foggia, Southern Italy, some vulnerability classes are defined. Based on the mechanical and geometrical features identified for each class, several ideal and representative buildings are generated, and their seismic behaviour is investigated through the variation of significant parameters. At the end, the capacity of the buildings is evaluated by performing simplified nonlinear analyses and, subsequently, by estimating the damage level of the sample through the definition of regional fragility curves.
\end{abstract}

\section{INTRODUCTION}

In the last few decades, the interest in the seismic behaviour of existing buildings has continuously grown, considering the high vulnerability to earthquakes exhibited by the existing building stock. In particular, the cities in the seismic-prone areas present a variegated portfolio of buildings, mainly including Reinforced Concrete (RC) and masonry ones.

To quantify the capacity of the existing building stock to cope seismic events, the first approach usually adopted is the sweep assessment of the structural health of all buildings 
through fast methods, based on the compilation of survey forms and retrieval of few observational parameters, which allow to provide a first prioritization useful for optimizing the funds destination to mitigate the seismic risk.

The scientific literature provides several examples of this approach [1], both for RC [2-5] and masonry [6-8] buildings. For example, the CARTIS form [9], developed by the Italian Civil Protection Department (DPC), within the ReLUIS project, allows to define homogenous urban sectors, which are composed by same typologies of RC and masonry buildings. The form is composed by 4 survey sections for collecting information about the building typologies, structural and constructive features in each urban sector of the Municipality investigated.

Another example is provided by the GNDT form [10], which allows to collect relevant information about some observational parameters (e.g. configuration in plan and elevation, structural and non-structural elements,...) on the basis of which an indirect methodology for calculating a seismic vulnerability index for each building investigate is implemented.

In [11], a methodology for the study of seismic vulnerability of historical centres at the regional scale was developed, based on the collection of data for 4519 housing units in the municipality of Foggia, through an ad-hoc electronic survey sheet.

Usually, the data collected with survey form methods are useful for providing results about regional seismic vulnerability and, in particular, can be used for computing regional fragility and losses curves through probabilistic analysis based on mechanical models. Also in this case, the scientific literature provides a lot of methodologies for achieving this goal both for RC [12-

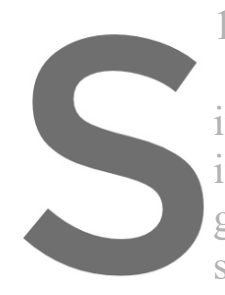
17] and masonry [18-19] buildings.

\section{In this framework} informatic tool useful it allows to extract, geo-referenced databas structured through the assignment of features buildings. [20-24].

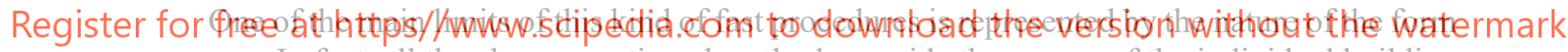
survey. In fact, all the above-mentioned methods provide the survey of the individual building units, both for RC and types. For RC buildings, this does not represent a big limitation but, for masonry buildings, the consideration of individual units does not allow to consider the typical structure of historical urban centres, which usually are rather urban aggregates.

The scope of this paper is the study of the urban masonry aggregates at regional scale, by matching the information provided by rapid visual survey methods and the data visualization provided in GIS environment. The proposed methodology, tested on a pilot example -the Municipality of Foggia- consists in the identification of the typical configuration of masonry buildings in a specified urban sector, that becomes an "index building" and the base for a mechanical model. According with the available information, some characteristic geometric and mechanical parameters are varied within predefined ranges, generating several numerical models of the same aggregate. Nonlinear analyses are performed according to the pushover approach, and regional fragility curves for serviceability and ultimate limit states are derived.

\section{SEISMIC VULNERABILITY OF MASONRY AGGREGATES: STATE OF ART}

The historical centres of the Mediterranean cities are prevalently constituted by masonry 
buildings, which usually were built chaotically, covering the greater part of the urban territory. In addition, the urban fabric was continually modified with the addition of masonry units in elevation or in plan to existing ones.

Because of this complex aggregation of masonry buildings, it is difficult to investigate the structural and seismic behaviour of the single units (due to the interaction among adjacent units), and of the entire aggregate (since it is difficult to investigate in detail all the geometrical and mechanical features of all interacting units, especially in a large-scale analysis).

Recent technical codes do not provide methodologies for tackling this issue and, in fact, they provide only methods to investigate the seismic behaviour of individual, independent masonry buildings. On the other hand, the scientific literature provides some studies that analyse the seismic vulnerability of masonry building compounds, considering both large scale and single scale analyses.

In [25], the building aggregates of the historical centre of Coimbra at regional scale was investigated, looking for the variation of some generic parameters, such as geometrical and mechanical features and seismic demand. In [26], an easy method for large scale analysis of seismic behaviour of masonry aggregates was proposed, consisting in a new form for defining the key features to use in numerical models. After the calibration of the methodology, it was tested on an historical centre, damaged from the Aquila Earthquake. The same author [27], developed a simple methodology to forecast the seismic behaviour of masonry aggregate, providing a design scheme for predicting the force distribution of each building unit.

\section{With regard to the}
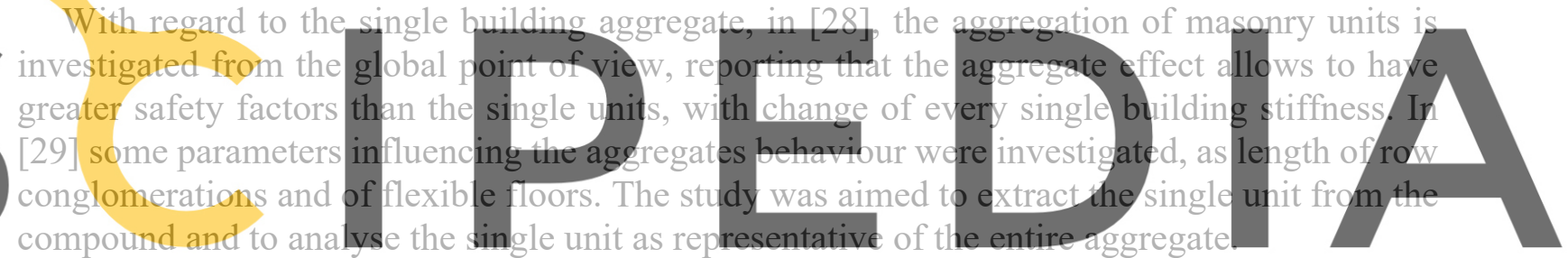

In [30], a study on the urban aggregates of Azores Islands was presented, wherein a

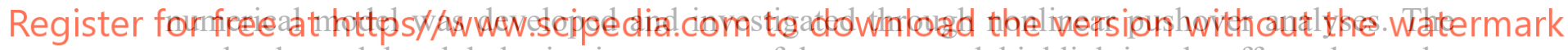
results showed the global seismic response of the compound, highlighting the effects due to the different heights of each adjacent unit.

In [31], a computational model was performed for the case study representative of Foggia and Sant'Agata di Puglia historical centres. The numerical model was investigated with nonlinear dynamic analyses, showing the differences, in terms of stress and strain distribution, obtained among each part of the compound. Other studies investigated also the interaction of both RC and masonry single units, as shown in [32].

The complexity of all the aspects involved in the seismic vulnerability of masonry urban aggregates, as reported by the scientific literature, has motivated the authors of this paper to propose a methodology for full investigating the effects of some geometrical and mechanical parameters in a large scale analysis. In particular, the procedure has been applied to a urban district of the Municipality of Foggia, generating a set of numerical models so that they can represent the typical configuration of the local building aggregates and computing the vulnerability curves. 


\section{SEISMIC VULNERABILITY OF URBAN MASONRY AGGREGATES AT THE REGIONAL SCALE: PROPOSAL OF A METHODOLOGY}

The proposed methodology allows to compute vulnerability curves to regional scale of masonry urban aggregates, following the steps shown in Figure 1.

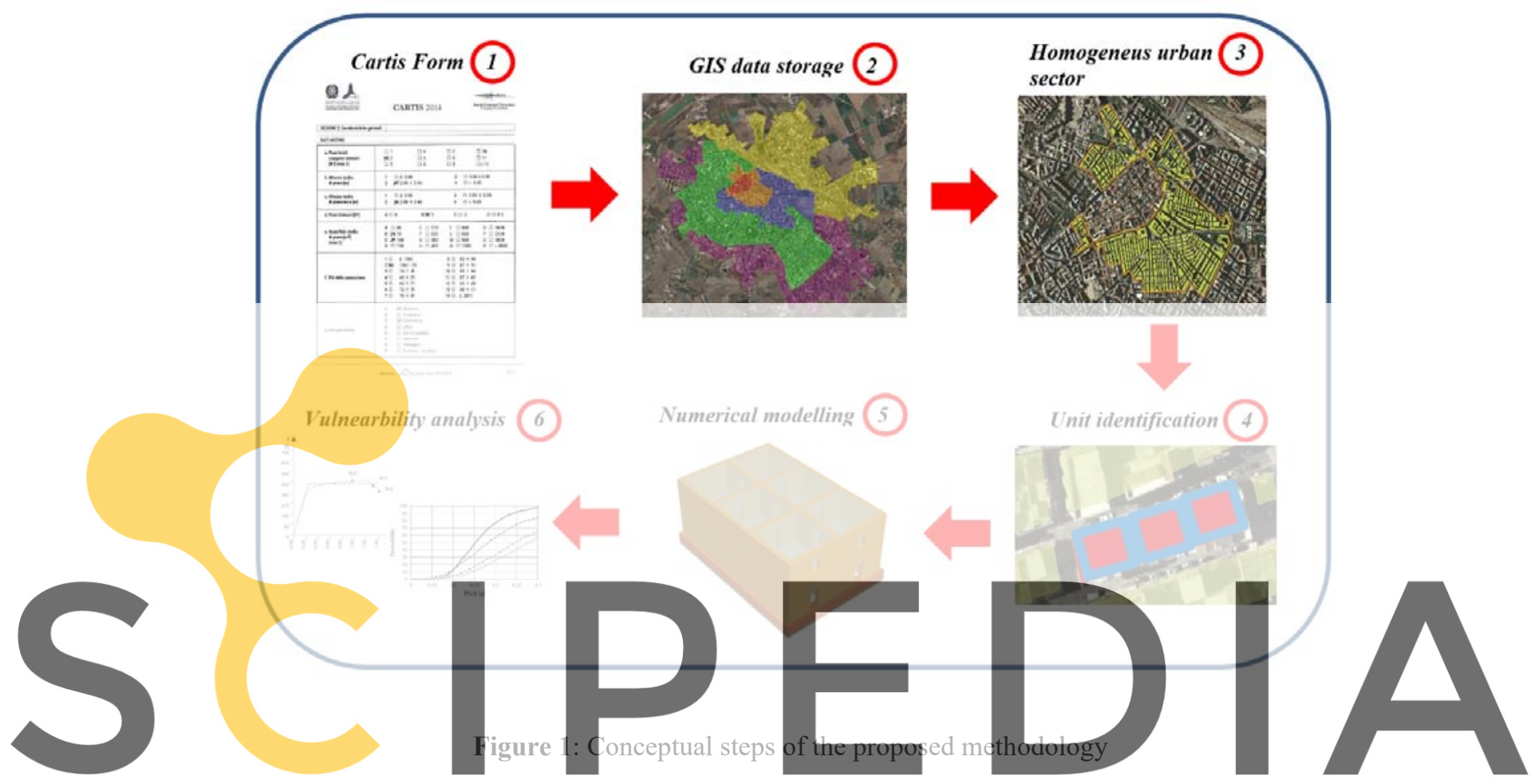

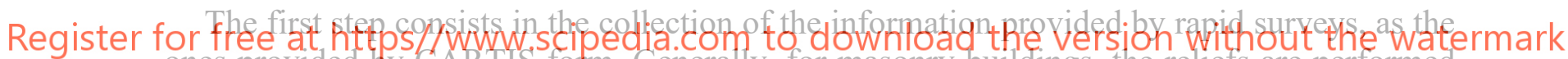
ones provided by CARTIS form. Generally, for masonry buildings, the reliefs are performed for single units and then, it is necessary to collect all data in a unique database, made through

GIS layers, in order to have a general view about each urban sector.

The second step consists in the generation of the GIS database, which allows to identify different urban sectors in the Municipality.

Once that the urban sectors are identified, it is possible to select the one to be investigated. In particular, we have chosen the one constituted mainly by aggregate masonry buildings, which coincides with a part of the historical centre. In the selected urban sector, a set of recurring building compound typologies has been identified.

By matching data and features collected for all surveyed units with those derived from Cartis forms, it has been possible to define a variation range for the properties of the reference building unit. In particular, using the GIS tools, the features and attributes of each record (e.g., height of the storeys, dimensions in plan, of the building units, percentage of openings in masonry panels, the masonry type, ...) can be extracted and processed in order to identify the input data for generating a representative FE numerical model of the entire compound. This model is then the starting basis for a sensitivity analysis for the study of the seismic vulnerability at large scale. Basing on the information collected through the above-mentioned methodology, a set of 
characteristic geometrical and mechanical parameters is selected for the single unit typology and a corresponding plausible range of variation is identified. Starting from this reference "index" model, a series of parametrical variation is performed on the geometrical and mechanical features by adopting the following procedure. According to [2], given $n$ parameters $\left(\mathrm{n}_{\mathrm{par}}\right)$ and a range subdivided into $\mathrm{m}$ steps ( $\left.\mathrm{m}_{\text {steps }}\right)$, the total number of FE models $\left(\mathrm{N}_{\text {models }}\right)$ to be generated is calculated as:

$$
N_{\text {models }}=\prod_{i=1}^{n_{\text {par }}} m_{\text {steps }, i}
$$

In order to define the numerical model of the entire aggregate, an elementary Reference Building Cell shall be repeated in-plan and in height, with the aim to cover the entire area of the compound displayed in the GIS map and reproduce the target aggregate.

Generally, according to the parameters chosen, it will be possible to define different reference units, which will be the basis for generating a series of building aggregates. In this work, for brevity sake, only one of the many possible type of building cells will be considered, in order to the number of possible combinations in the sensitivity analysis.

For each FE model (i.e. one random realization of the target aggregate, obtained by repeating a single cell on a 3D grid), nonlinear pushover analyses are performed and the vulnerability index is computed in terms of capacity/demand (C/D) ratio for the different limit states, .In order to compute the vulnerability curves, the values of $\mathrm{C} / \mathrm{D}$ are evaluated for increasing levels of the seismic demand (this is achieved by progressively increasing the return periods that define the design spectrum, correspondingly e
regional vulnerability curve for that building a
More in detail, each regional vulnerab lity
models with a capacity-demand ratio of the en
values of the Intensity Measure (IM) (that is PGA), conditioned byeach linit state assumec.
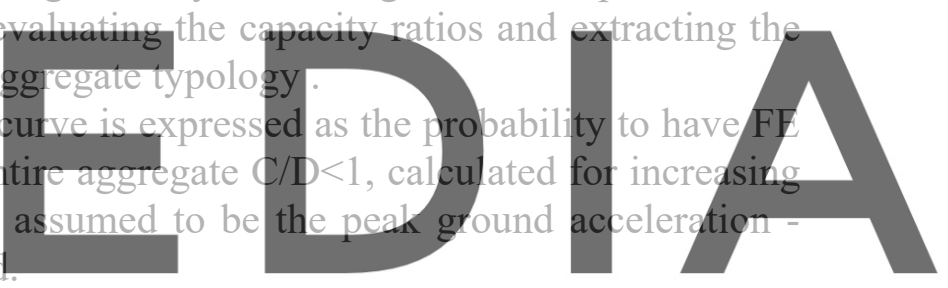

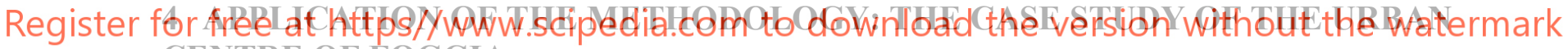 CENTRE OF FOGGIA}

By following the framework described in Figure 1, the proposed methodology has been applied to the municipality of Foggia, Southern Italy. Within the activities of the ReLUIS project, the Cartis forms have been compiled for the city and the data have been collected into a GIS database. Based on the investigations about building typologies, both for RC [33] and masonry buildings, six urban sectors have been identified, as shown in Figure 2.

The 6 urban sectors listed in the legend of Figure 2 have been sorted according to the more frequent building structural typology, basing on the attributes provided by the Cartis form (e.g., construction year, materials, shape,...). In this case, as it often happens in Southern Italy, the main part of the historical building stock is located in the city centre, covering the urban sectors named $\mathrm{C} 01-\mathrm{C} 02-\mathrm{C} 03$. We focused on the urban sector $\mathrm{C} 02$, as shown in Figure 3, dating back to 1700 . The entire urban sector is composed mainly by masonry buildings (about the $60 \%$ of all buildings) classified, in the framework of CARTIS data collection, in 2 different structuraltypological classes, surveyed using CARTIS form which contain general data, geometrical features and the information for identifying the mechanical parameters. 


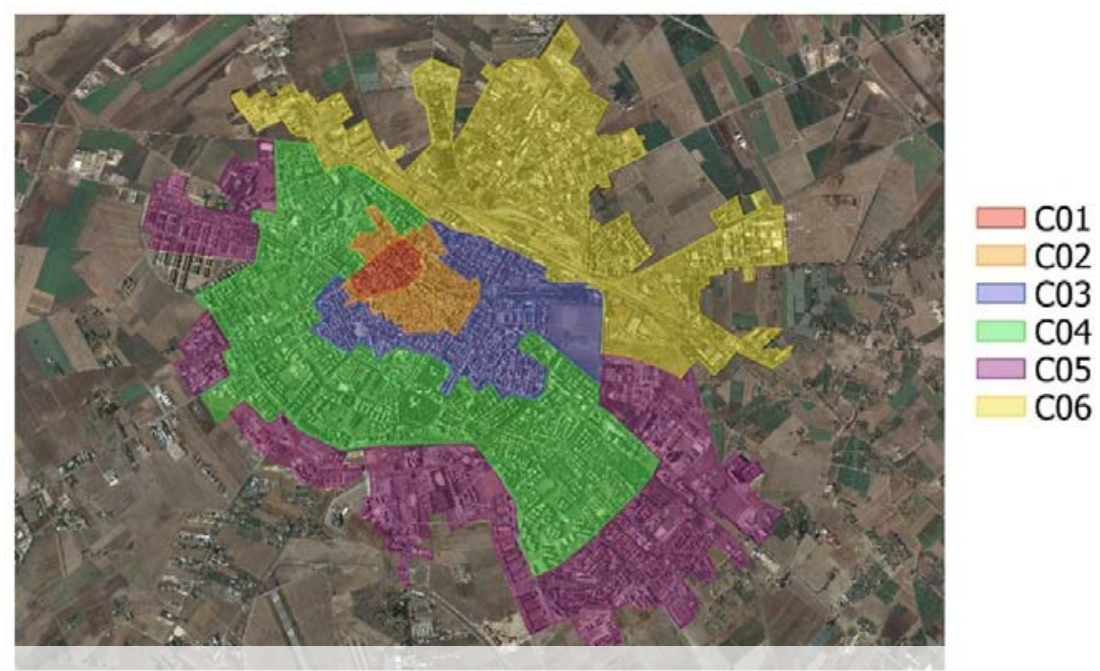

Figure 2: Urban sectors of Foggia Municipality, through GIS elaboration

From Figure 3 it can be observed that in the considered sector urban aggregates of different shapes are present. Anyway, they are mostly rectangular, and the typology of the basic building unit is a duplex terrace configuration. By analysing the information of the Cartis form and taking an average of the values detected, we have defined the reference building cell that represents the more frequent structural typology in that urban sector and that is repeated in the

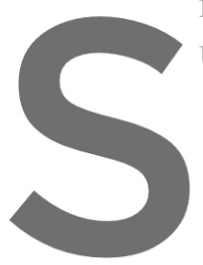

urban compounds

Register for free at https//www.scipedia.com to download the version without the watermark
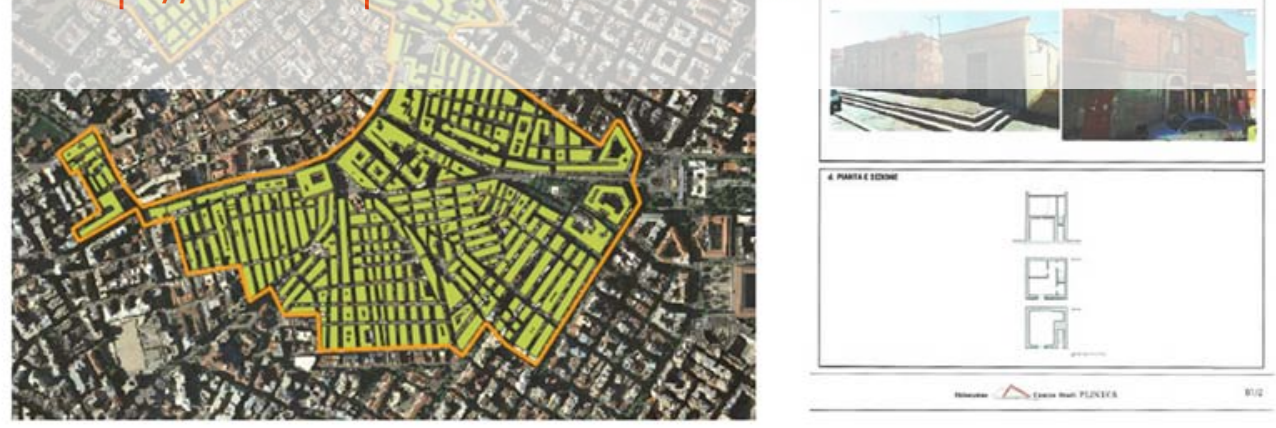

Figure 3: View of the historical centre of Foggia and structural typology identification through CARTIS form.

This reference unit is a rectangular masonry building of in-plan dimension of $10 \mathrm{~m} \mathrm{x} 15 \mathrm{~m}$ and interstorey height of $3.5 \mathrm{~m}$. All the perimetral walls and the central wall in the longitudinal direction are load-bearing walls, with a width of $40 \mathrm{~cm}$. The central walls have a width of $20 \mathrm{~cm}$ and are partitions. On the shorter side some openings are present and, in particular, it is assumed, that each wall presents 2 windows of dimensions $80 \mathrm{~cm} \times 120 \mathrm{~cm}$ and 2 doors of 
dimensions $90 \mathrm{~cm} \times 220 \mathrm{~cm}$. The floor is a ribbed slab with RC joists and hollow clay blocks $16 \mathrm{~cm}$ high, covered completed by a RC plate $5 \mathrm{~cm}$ thick. Regarding materials, according to the reports made by surveyors, the masonry panels are made by regular limestone blocks, similar to those provided in the Italian Building Code.

\subsection{Numerical modelling and sensitivity analysis}

The numerical modelling of the reference cell and of the overall aggregate has been carried out through the software POR2000 [34], which use the methodology proposed by Tomaževic [35]. In particular, masonry walls are modelled as shell elements with fixed restraints at the base; horizontal slabs are considered as rigid diaphragms through the application of internal constraints. The applied loads are permanent and live loads, partially computed by the software, according to the geometrical and mechanical features of the masonry, and partially implemented by the user, according to the specific destination use (in this case, residential).

With regard to the nonlinear behaviour, as suggested by POR methodology, each masonry wall is assumed to have a shear-type behaviour, with the limit displacement, for each limit state, defined according to Section 4.2.

The procedure, at this point, provides firstly the choice of a specific Reference Building Cell, with a defined geometry, and subsequently the sensitivity analysis. With regard to the dimension of the urban aggregate, the first parameter varied is the clustering pattern of the cells in order to fill the in-plan footprint shown in the GIS map. As shown in Figure 4, in the urban

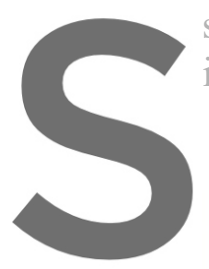
sector analysed, 4 typologies of buikding a
identified.
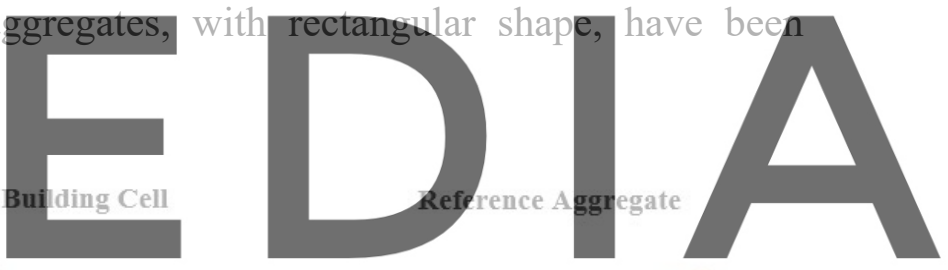

Register for free at https//www.scipedia.com to download the version without the watermark
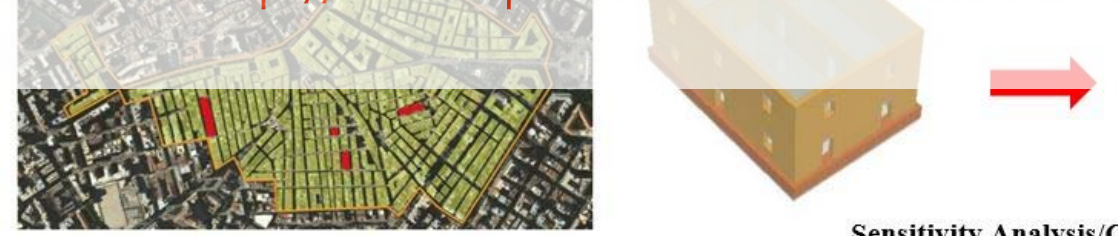

Sensitivity Analysis/Clustering

Figure 4: Left: identification of the recurrent building blocks in the Sector C02. Right: an example of random clustering of the building cells.

Table 1 reports the ratio between the sides of the rectangular building block, which will be reproduced by clustering the single cells according to the pattern of a duplex terraced buildings. In addition, Table 1 reports the geometrical and mechanical parameters varied in the sensitivity analysis, which are the height of masonry aggregate (a maximum of 2 storeys is assigned, with the second storey that can recess by $1 / 2$ and $1 / 4$ from the ground floor - ) and the mechanical parameter of the limestone, defined according to the range provided by the annex of the Italian Building Code [36], and indicated in the table with the symbol $\sigma_{\mathrm{m}}$, which is the compression strength of the masonry. 
Table 1: List of the parameters varied in the sensitivity analysis and variation range adopted.

\begin{tabular}{|c|c|c|c|}
\hline \multirow{2}{*}{ Ratio between aggregate sides } & \multirow{2}{*}{ Number of storeys } & \multicolumn{2}{|c|}{$\sigma_{\mathrm{m}}\left(\mathrm{N} / \mathrm{mm}^{2}\right)$} \\
\hline & & $\min$ & $\max$ \\
\hline \multirow{4}{*}{$1: 1$} & 1 & \multirow{4}{*}{2,00} & \multirow{4}{*}{3,20} \\
\hline & 2 & & \\
\hline & $1+1 / 2$ & & \\
\hline & $1+1 / 4$ & & \\
\hline \multirow{4}{*}{$1: 2$} & 1 & \multirow{4}{*}{2,00} & \multirow{4}{*}{3,20} \\
\hline & 2 & & \\
\hline & $1+1 / 2$ & & \\
\hline & $1+1 / 4$ & & \\
\hline \multirow{4}{*}{$1: 3$} & 1 & \multirow{4}{*}{2,00} & \multirow{4}{*}{3,20} \\
\hline & 2 & & \\
\hline & $1+1 / 2$ & & \\
\hline & $1+1 / 4$ & & \\
\hline \multirow{4}{*}{$1: 4$} & 1 & \multirow{4}{*}{2,00} & \multirow{4}{*}{3,20} \\
\hline & 2 & & \\
\hline & $1+1 / 2$ & & \\
\hline & $1+1 / 4$ & & \\
\hline
\end{tabular}

The other relevant mechanical parameters of the masonry are associated to the value of $\sigma_{\mathrm{m}}$ : shear strength of the masonry to, (which varies betwees modulus E, which varies betv between 400 and 500 $\mathrm{N} / \mathrm{m}^{3}$

According to the investigated in nonlinear field through pushov
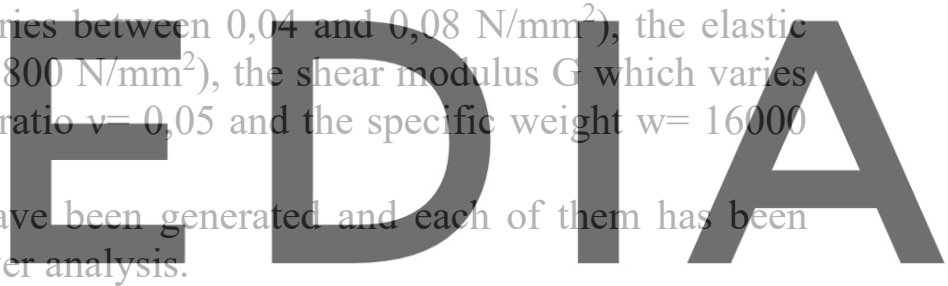

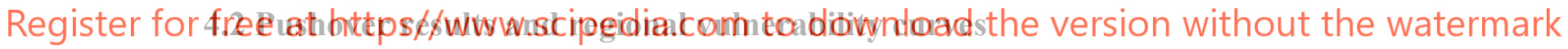

It is worth highlighting that in the analyses only in-plane failure mechanisms have been considered, i.e., only global response has been taken into account. Assuming the centre of the mass of the last storey as the control node, for each capacity curve the software provides the different performance points $\left(\mathrm{V}_{\mathrm{b}}\right.$ - roof displacement $\left.\delta \mathrm{R}\right)$ corresponding to the attainment of the limit states. In particular, according to the Italian Building Code, the limit state thresholds considered are defined as follows:

- for immediate occupancy (IO), the limit state threshold is defined as the value of the horizontal displacement equal to $0.3 \%$ of the generic masonry panel height;

- for life safety (LS), the limit state threshold is defined as the value of the horizontal displacement obtained to a reduction of $10 \%$ of the maximum $\mathrm{V}_{b}$ in the pushover curve;

- for near collapse (NC) limit state, the limit state threshold is defined as the value of the horizontal displacement corresponding to a reduction of $15 \%$ of the maximum $\mathrm{V}_{\mathrm{b}}$ in the pushover curve.

According to the N2 method, the Capacity/Demand ratios are computed for all the models and limit states. The seismic demand has been assumed as the one provided by a code spectrum 
computed for the average coordinates of the sector $\mathrm{C} 02$, for the return periods: $\mathrm{T}_{\mathrm{R}}=50$ years for $\mathrm{IO}, \mathrm{T}_{\mathrm{R}}=475$ years for $\mathrm{LS}, \mathrm{T}_{\mathrm{R}}=975$ years for $\mathrm{NC}$. In order to compute the vulnerability curves for all the considered limit states, the $C / D$ values have been recomputed by changing the $T_{R}$ of the spectrum and increasing the seismic demand. In particular, the computations have been performed for other values of $\mathrm{T}_{\mathrm{r}}$. The results in terms of $\mathrm{C} / \mathrm{D}$ obtained for all the models, which are 96 values for each limit state, have been processed for the computation of urban vulnerability curves for the urban sector considered, assuming as IM the ag parameter. These curves express the probability of exceeding the IM corresponding to a safety level greater than $1(C / D>1)$ for the Building aggregates in the urban sector investigated, conditioned by the above-defined limit state's threshold.

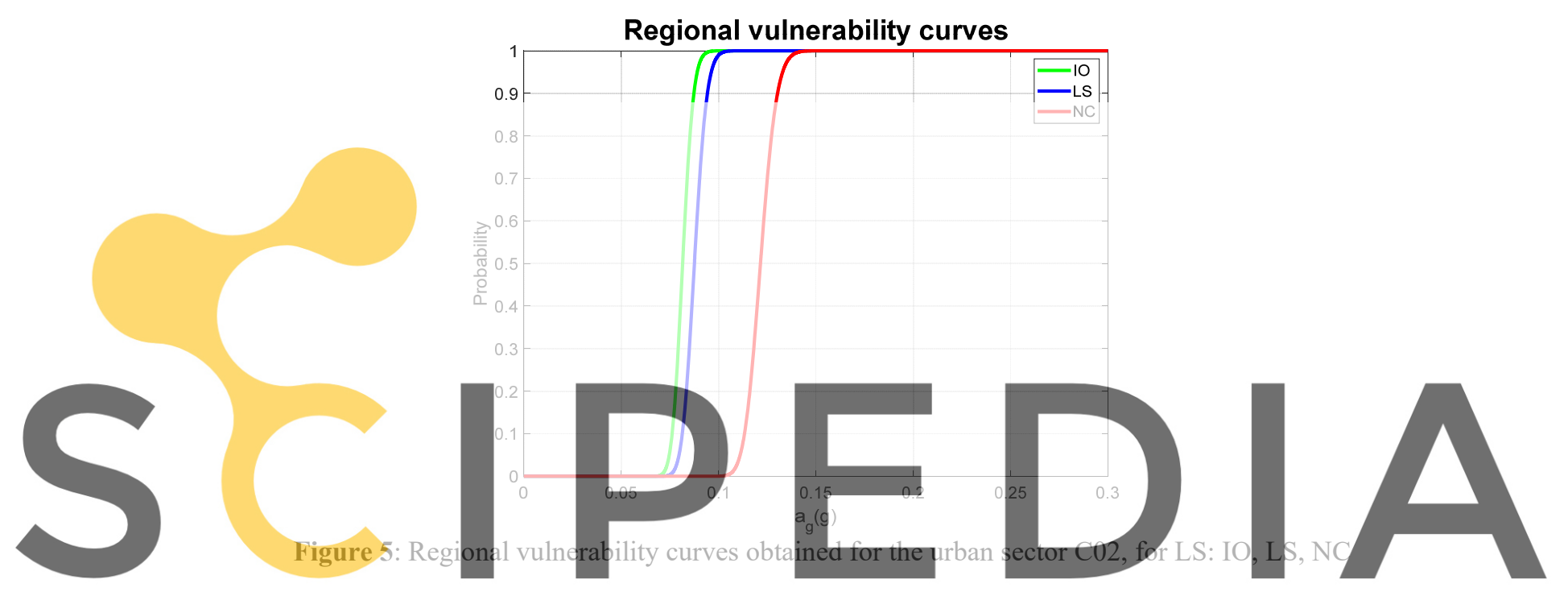

The results obtained in terms of vulnerability curyes are shown in Figure 5, while the parameters

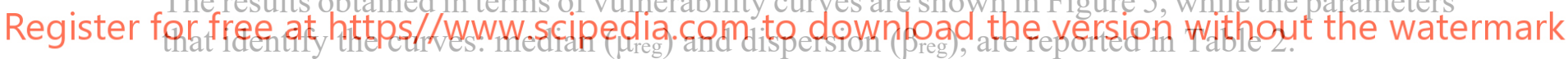

Table 2: Median and dispersion of regional vulnerability curves

\begin{tabular}{ccc}
\hline $\begin{array}{c}\text { Vulnerability } \\
\text { curves }\end{array}$ & $\mu_{\text {reg }}$ & $\beta_{\text {reg }}$ \\
\hline IO & 0.082 & 0.053 \\
\hline LS & 0.088 & 0.057 \\
\hline NC & 0.122 & 0.058 \\
\hline
\end{tabular}

\section{CONCLUSION AND FUTURE DEVELOPMENTS}

In this work, a mechanical-based procedure is developed for computing the vulnerability curves of masonry building aggregates at the large scale. In particular, input data are obtained by combining information extrapolated from Cartis forms and data stored in a GIS platform.

By using data about the recurrent structural typologies defined within each of the 
homogeneous urban sectors detected in the municipality, it has been possible to identify the sector constituted mainly by masonry buildings, located in the historical centre. Moreover, a Reference Building Cell has been defined, which can be spatially repeated in order to cover the aggregates' shape as seen in the GIS map.

By numerically modelling the Building aggregate and varying the geometrical and mechanical features within plausible variation ranges, different numerical configurations have been generated and investigated by nonlinear pushover analysis. The values of the vulnerability indexes, expressed in terms of $\mathrm{C} / \mathrm{D}$, have been computed for increasing seismic demands. and vulnerability curves for three limit states have been derived.

This procedure has been applied to the case study of Foggia, Southern Italy, where an extensive survey campaign has been performed. After storing and organizing data storage in the GIS environment, attention has been focused on the masonry buildings of a specific urban sector, conceiving a proper Reference Building Cell. Varying some characteristic parameters, according to the information derived from CARTIS form, a sensitivity analysis has been performed and vulnerability curves for 3 limit states have been plotted.

The future developments will provide the extension of the analyses on the same urban sector, by increasing the number of reference cells. Furthermore, additional numerical combinations will be proposed, accounting for more information and more variables, in order to compute full vulnerability curves for the urban sector investigated.

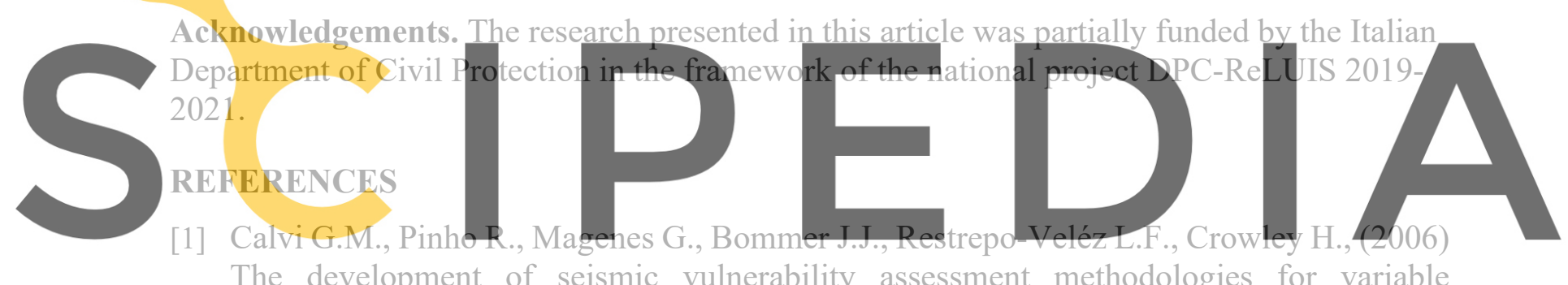

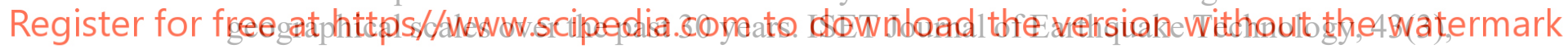
75-104.

[2] G. Uva, P. L. Ciampoli, V. Leggieri, A. Nettis, and S. Ruggieri, A mechanical approach for estimating regional fragility curves of existing RC buildings stock in Puglia, in COMPDYN 2019 7th ECCOMAS Thematic Conference on Computational Methods in Structural Dynamics and Earthquake Engineering (2019).

[3] Uva G, Sangiorgio V., Ciampoli P.L., Leggieri V, Ruggieri S., A novel rapid survey form for the vulnerability assessment of existing building stock based on the "Index Building" approach, Conference Proceedings - IEEE International Conference on Systems, Man and Cybernetics (2019), Bari 6-9 Oct. DOI:10.1109/SMC.2019.8914063

[4] Perrone D, et al, Rapid visual screening for seismic evaluation of RC hospital buildings, Structures (2015), http://dx.doi.org/10.1016/j.istruc.2015.03.002

[5] Porco F., Ruggieri S., Uva G., (2018) Seismic assessment of irregular existing building: appraisal of the influence of compressive strength variation by means of nonlinear conventional and multimodal static analysis, Ingegneria Sismica, 35(3), pp. 64-86

[6] Lagomarsino S., Podesta S. (2004). Seismic vulnerability of ancient churches: I. Damage assessment and emergency planning. Earthquake Spectra, 20(2), pp. 377-394.

[7] Uva G, Sangiorgio V., Ruggieri S., Fatiguso F., Structural vulnerability assessment of 
masonry churches supported by user-reported data and modern Internet of Things (IoT), Measurement (2019), https://doi.org/10.1016/j.measurement.2018.08.014;

[8] De Matteis, G., Brando, G. \& Corlito, V. Predictive model for seismic vulnerability assessment of churches based on the 2009 L'Aquila earthquake. Bull Earthquake Eng 17, 4909-4936 (2019). https://doi.org/10.1007/s10518-019-00656-7.

[9] G. Zuccaro, M. Dolce, D. De Gregorio, E. Speranza, and C. Moroni, La Scheda Cartis Per La Caratterizzazione Tipologico-Strutturale Dei Comparti Urbani Costituiti Da Edifici Ordinari. Valutazione dell'esposizione in analisi di rischio sismico $34^{\circ}$ Convegno Nazionale GNGTS, Trieste, 17-19 novembre 2015.

[10] A. Bernardini (A cura di), La vulnerabilità degli edifici: valutazione a scala nazionale della vulnerabilità sismica degli edifici ordinari, CNR-Gruppo Nazionale per la Difesa dai Terremoti - Roma, 2000, 175 pp. + CD-ROM allegato

[11] G. Uva, C.A. Sanjust, S. Casolo, M. Mezzina, ANTAEUS project for the regional vulnerability assessment of the current building stock in historical centers International Journal of Architectural Heritage, 10(1), pp. 20-43, 2016. http://dx.doi.org/10.1080/15583058.2014.935983

[12] FEMA (2001) HAZUS99 Technical Manual. Service Release 2. Federal Emergency Management Agency, Washington, D.C., USA.

[13] Cosenza E., Manfredi G., Polese M., Verderame G.M., (2005) A multi-level approach to the capacity assessment of existing RC buildings. J. of Earthq. Eng., 9(1), 1-22.

[14] Borzi B., Pinho, R. Crowley H. (2008). Simplified pushover-based vulnerability analysis for large-scale assessment of RC buildings. Engineering Structures 30(3), 804-820.

[15] Del Vecchio C., Gentile R., Di Ludovico M., Uva G., Pampanin S. (2018). Implementation and Validation of the Simple Lateral Mechanism Analysis (SLaMA) for the Seismic Performance Assessment of a Damaged Case Study Building, Journal of Earthquake Engineering, https://doi.org/10.1080/13632469.2018.1483278

[16] Gentile R., del Vecchio C., Pampanin S., Raffaele D., Uva G. (2019). Refinement and Validation of the Simple Lateral Mechanism Analysis (SLaMA): Procedure for RC Frames. Journal of Earthquake Engineering. doi:10.1080/13632469.2018.1560377

[17] Ruggieri, S., Porco, F. \& Uva, G. A practical approach for estimating the floor deformability in existing RC buildings: evaluation of the effects in the structural response and seismic fragility. Bull. Earthq. Eng. (2019).

[18] Lagomarsino S. and Giovinazzi S., Macroseismic and mechanical models for the vulnerability and damage assessment of current buildings, Bull. Earthq. Eng. 4, 415-443, (2006).

[19] Borzi B., Crowley H., Pinho R. Simplified Pushover-Based Earthquake Loss Assessment (SP-BELA) Method for Masonry Buildings, International Journal of Architectural Heritage, (2008) 2:4, 353-376, DOI: 10.1080/15583050701828178A

[20] Y. Liu, Z. Li, B. Wei, X. Li and B. Fu, Seismic vulnerability assessment at urban scale using data mining and GIScience technology: application to Urumqi (China), Geomatics, Nat. Hazards Risk 10, 958-985 (2019).

[21] L. Matassoni, S. Giovinazzi, M. Pollino, A. Fiaschi, L. La Porta and V. Rosato, A Geospatial Decision Support Tool for Seismic Risk Management: Florence (Italy) Case Study, Computational Science and Its Applications - ICCSA 2013, 7974, 278-293 (2013).

[22] G. Uva, M. Dassisti, F. Iannone, G. Florio, F. Maddalena, M. Ruta, A. Grieco, I. 
Giannoccaro, V. Albino, M. Lezoche, A. Aubry, A. Giovannini, A. Buscicchio, Y. Eslami, V. Leggieri, Modelling Framework for Sustainable Co-management of Multi-purpose Exhibition Systems: The 'Fiera del Levante' Case, Procedia Engineering 180, 812-821, (2017).

[23] Uva G., Leggieri V., Morrone M., USE of data derived by different sources for the seismic vulnerability assessment of current building stock in GIS environment: an application to the municipality of Bisceglie, Italy. $3^{\text {rd }}$ International Conference on International Conference on Recent Advances in Nonlinear Design, Resilience and Rehabilitation of Structures, CoRASS 2019 H. Barros, C. Ferreira, José M. Adam and Norb Delatte (Eds)

[24] Uva G., Leggieri V., Mastrodonato G., Proposal of a procedure for gathering data for the structural and energy classification of residential building stock: a case study in Puglia. $3^{\text {rd }}$ International Conference on International Conference on Recent Advances in Nonlinear Design, Resilience and Rehabilitation of Structures, CoRASS 2019 H. Barros, C. Ferreira, José M. Adam and Norb Delatte (Eds)

[25] Pagnini LC, Vicente R, Lagomarsino S, Varum H. A mechanical model for the seismic vulnerability assessment of old masonry buildings. Earthq Struct 2011;2(1)

[26] Formisano A., Florio G., Landolfo R., Mazzolani F. Numerical calibration of an easy method for seismic behaviour assessment on large scale of masonry building aggregates. Advances in Engineering Software 80 (2015) 116-138

[27] Formisano A. Theoretical and Numerical Seismic Analysis of Masonry Building Aggregates: Case Studies in San Pio Delle Camere (L'Aquila, Italy). Journal of Earthquake Engineering, 00:1-19, 2016

[28] Ramos LF, Lourenço PB. Modeling and vulnerability of historical city centers in seismic areas: a case study in Lisbon. Eng Struct 2004;26(9):1295-310.

[29] Senaldi I, Magenes G, Penna A. Numerical investigations on the seismic response of masonry building aggregates. Adv Mater Res 2010;133-134:715-20.

[30] Casolo S., Sanjust C. A., Uva G., Diana V., Seismic modelling and analysis of masonry building in aggregate: a case study. Compdyn 2017 6th ECCOMAS Thematic Conference on Computational Methods in Structural Dynamics and Earthquake Engineering M. Papadrakakis, M. Fragiadakis (eds.) Rhodes Island, Greece, 15-17 June 2017

[31] Fagundes C., Bento R., Cattari S., On the seismic response of buildings in aggregate: Analysis of a typical masonry building from Azores, Structures (2016).

[32] Ferrito T, Milosevic J, Bento R, Seismic vulnerability assessment of a mixed masonry-RC building aggregate by linear and nonlinear analyses. Bull Earthquake Eng. (2016).

[33] Aiello, M.A., Ciampoli, P.L., Fiore, A., Perrone, D., Uva, G. (2017a) Influence of infilled frames on seismic vulnerability assessment of recurrent building typologies, Ingegneria Sismica, 34(4), pp. 58-80

[34] Tomazevic, M., "The computer program POR", Report ZRMK, 1978 (in Slovenian)

[35] https://www.newsoft-eng.it/software/por-2000/

[36] Circolare 21 gennaio 2019, n.7 C.S.LL.PP. Istruzioni per l'applicazione dell'Aggiornamento delle "Norme tecniche per le costruzioni” di cui al DM 17/01/2018. 